\title{
Universiteit
}

Leiden

The Netherlands

\section{Procoagulant factors and the risk of myocardial infarction in young} women

Tanis, B.C.; Algra, A.; Graaf, Y. van der; Helmerhorst, F.M.; Rosendaal, F.R.

\section{Citation}

Tanis, B. C., Algra, A., Graaf, Y. van der, Helmerhorst, F. M., \& Rosendaal, F. R. (2006). Procoagulant factors and the risk of myocardial infarction in young women. European Journal Of Haematology, 77(1), 67-73. Retrieved from https://hdl.handle.net/1887/5009

Version: $\quad$ Not Applicable (or Unknown)

License:

Downloaded from: https://hdl.handle.net/1887/5009

Note: To cite this publication please use the final published version (if applicable). 


\section{Procoagulant factors and the risk of myocardial infarction in young women}

\begin{abstract}
Tanis B, Algra A, van der Graaf Y, Helmerhorst F, Rosendaal F. Procoagulant factors and the risk of myocardial infarction in young women.

Abstract: Objectives: We investigated whether elevated levels of factor VIII, IX and XI is associated with myocardial infarction (MI) in young women. In addition, we studied ABO blood group, von Willebrand factor (VWF) and C-reactive protein (CRP). Methods and results: We compared 200 women with MI before age 49 years with 626 controls from a population-based case-control study. Mean levels of factor VIII activity (VIII), von Willebrand factor antigen (VWF), factor IX activity (IX) were higher in patients $(133,134$ and $132 \mathrm{IU} / \mathrm{dL})$ than in controls $(111,107$ and $120 \mathrm{IU} / \mathrm{dL}$, respectively). Mean levels of factor XI (XI) were equal in patients $(114 \mathrm{IU} / \mathrm{dL})$ and controls $(113 \mathrm{IU} / \mathrm{dL})$. The odds ratio (OR) for MI for blood group non-O vs. O was $1.6[95 \%$ confidence interval (CI) 1.1-2.3]. The OR adjusted for age, index year and area of residence for the highest quartile $>150 \mathrm{IU} / \mathrm{dL}$ of factor VIII was 2.7 (95\% CI 1.6-4.6), of VWF 4.7 (95\% CI 2.3-9.7), of factor IX 2.6 (95\% CI 1.3-5.4) and of factor XI 0.9 (95\% CI 0.5-1.4), all compared with the lowest quartile $<100 \mathrm{IU} / \mathrm{dL}$. Conclusions: Non-O blood group, high VWF, factor VIII and factor IX levels are associated with an increased risk of MI in young women, while high factor XI levels are not.
\end{abstract}

\author{
Bea Tanis', Ale Algra ${ }^{2,3,5}$, Yolanda \\ van der Graaf', Frans Helmerhorst ${ }^{4}$, \\ Frits Rosendaal ${ }^{5}$ \\ ${ }^{1}$ Department of Haematology, Leiden University Medical \\ Centre, Leiden; ${ }^{2}$ Julius Centre for Health Sciences and \\ Primary Care, Utrecht University Medical Centre, \\ Utrecht; ${ }^{3}$ Department of Neurology, Utrecht University \\ Medical Centre, Utrecht; Departments of ${ }^{4}$ Gynaecology \\ and Reproductive Medicine, and ${ }^{5}$ Clinical Epidemiology, \\ Leiden University Medical Centre, Leiden, the \\ Netherlands \\ Key words: case-control study; coagulation factors; \\ myocardial infarction; risk factor; women \\ Correspondence: Prof. Dr F.R. Rosendaal, Department of \\ Clinical Epidemiology, Leiden University Medical Centre, \\ C9-P, P0 Box 2600, 2300 RC Leiden, the Netherlands \\ Tel: 0031715264037 \\ Fax: 0031715266994 \\ e-mail: f.r.rosendaal@lumc.nl \\ Accepted for publication 30 January 2006
}

Elevated levels of coagulation factor VIII, IX and $\mathrm{XI}$ are associated with an increased risk of venous thrombosis (1-7). The role of factor VIII, IX and $\mathrm{XI}$ in the pathogenesis of myocardial disease is less clear, although associations between risk factors for cardiovascular disease, i.e. age, hyperlipidaemia, high blood pressure, diabetes, obesity, menopausal status and social class, and elevated factor VIII or IX levels have been described (8-11).

Blood group and von Willebrand factor (VWF) are important determinants of factor VIII levels. Lower levels of factor VIII and VWF are present in subjects with blood group $\mathrm{O}$ compared with those with blood group A, B or AB. Elevated factor VIII levels have been associated with ischaemic heart disease in men (12-14).

For VWF, the main determinants are ABO blood group, age $(15,16)$, acute-phase reaction and endothelial dysfunction $(17,18)$. Some evidence for the role of factor VIII and VWF in cardiovascular disease was found in cohort studies (19-22). Moreover, patients with factor VIII and IX defici- ency (haemophilia A and B) are protected against ischaemic heart disease $(23,24)$.

Elevated levels of VWF and factor VIII may also be the result of endothelial damage, i.e. be markers for existing atherosclerosis. C-reactive protein (CRP) is a sensitive marker for underlying systemic inflammation and acute-phase reaction, and may be used to investigate the role of an acute-phase response in bringing about increased factor VIII and VWF levels. In postmenopausal women, CRP was found to be a strong risk factor for cardiovascular events (25), but virtually no data are available in premenopausal women. In men, CRP predicts risk with elevations that can largely be explained by more conventional risk factors $(26,27)$.

Factor XI and IX are zymogens of serine proteases and are converted to active enzymes during blood coagulation. Factor IX belongs with factor X, VII and prothrombin to the vitamin Kdependent factors, which require vitamin $\mathrm{K}$ for their complete synthesis. Factor XI, IX and VIII are required for continued thrombin generation 
and maintenance of fibrin formation (28). After the activation of factor XI by thrombin, additional thrombin formation takes place inside the fibrin clot via the intrinsic pathway (29). The role of factor XI in haemostasis can be seen as a combination of procoagulant and antifibrinolytic actions (30).

In the present study, we investigated the association between elevated factor VIII, IX and XI activity and the risk of myocardial infarction (MI) in young women. In this specific patient group, arterial thrombosis is presumed to play a more important role than in older patients who have relatively more atherosclerosis and longer exposure to major cardiovascular risk factors. To investigate the mechanisms of genetic and acquired factors that influence coagulation factors, we also determined the role of blood group, VWF, CRP and fibrinogen on the risk of MI.

\section{Patients and methods}

Design

The study design of this population-based casecontrol study on acute MI in young women in the Netherlands, the Risk of Arterial Thrombosis In relation with Oral contraceptive use (RATIO) study, has been described in detail previously (31). In summary, we included 248 patients with a first acute MI between 18 and $49 \mathrm{yr}$ of age, who were selected from university and regional hospitals in the period January 1990 to October 1995. Controls consisted of 925 women, contacted by random-digit dialling, stratified for age, index year of MI and area of residence. All consenting patients and control women completed a standardized mail questionnaire on demographics, oral contraceptive use, history of hypertension, diabetes and hypercholesterolaemia, cigarette smoking, alcohol, height and weight, and family history of cardiovascular disease. Women were classified as hypertensive, diabetic or hypercholesterolaemic when they reported a physician's diagnosis or were taking medication for these conditions before the index date. Body mass index (BMI) was calculated as body weight $(\mathrm{kg})$ divided by height squared $\left(\mathrm{m}^{2}\right)$. We considered as obese any woman with a BMI $\geq 27.3 \mathrm{~kg} / \mathrm{m}^{2}$. Women were classified as current smokers when they reported smoking in the year before the index date. A family history of cardiovascular disease was defined as the presence of MI, stroke or peripheral arterial disease in one or both parents before $60 \mathrm{yr}$ of age. For the analyses of factor IX levels, patients on oral anticoagulant medication were excluded $(n=21)$.
Blood collection and plasma assays

We obtained blood samples for measurement of coagulation factors from 200 patients and 626 control women with a mean interval of $5 \mathrm{yr}$ after the index date for cases and controls. Blood was collected from the antecubital vein into tubes containing 0.1 volume $0.106 \mathrm{~mol} / \mathrm{L}$ trisodium citrate. Plasma was prepared by centrifugation for $10 \mathrm{~min}$ at $2000 \mathrm{~g}$ at room temperature and stored at $-70^{\circ} \mathrm{C}$, until use. $\mathrm{ABO}$ blood groups were determined by routine serum blood-grouping procedures. Factor VIII activity (VIII), factor IX activity (IX) and factor XI activity (XI) levels were measured by a one-stage clotting assay with factor VIII-, factor IX- and factor XI-deficient plasma, respectively, and automated activated partial thromboplastin time (APTT; Organon Teknika, Boxtel, the Netherlands) on a STA (Diagnostica Stago, Boehringer Mannheim). VWF antigen (VWF) was measured by an enzyme-linked immunosorbent assay (ELISA), using polyclonal antibodies (Dako, High Wycombe, UK). All measurements were performed in duplicate in two different dilutions, with a coefficient of variation $<10 \%$. Plasma levels were expressed as units per decilitre (IU/dL). By definition, $1 \mathrm{dL}$ pooled normal plasma contains 100 units. Fibrinogen was determined according to Von Clauss using the reagents of Behringwerke AG (Marburg, Germany). CRP levels were measured by an enzyme immunoassay (CRP EAI HS, Kordia, Leiden, the Netherlands). Plasma CRP concentration of $10 \mathrm{mg} / \mathrm{L}$ and above was classified as $\geq 10 \mathrm{mg} / \mathrm{L}$. The technician was unaware of whether samples were from patients or control women. The study protocol was approved by the Ethical Committees of all participating hospitals and all women gave informed consent.

\section{Statistical analysis}

Mean levels of factor VIII, factor IX, factor XI, VWF, and fibrinogen according to 10 -yr age categories were compared between patients and control women; for CRP, the median was used. ABO blood group was dichotomized in blood group non-O (A, B and AB) vs. O. Quartiles of factor VIII, factor IX, factor XI, VWF, fibrinogen and CRP levels were defined to assess a dose-response relationship between levels and the risk of MI, and risks were calculated relative to the lowest stratum, the reference category. Odds ratios (OR) were calculated as a measure of relative risk with $95 \%$ confidence intervals $(95 \% \mathrm{CI})$ and were derived from the logistic 


\section{Procoagulant factors and the risk of myocardial infarction}

regression model. The odds ratios were adjusted for the stratification variables (age, index year and area of residence) and putative confounders.

\section{Results}

Mean levels of factor VIII, factor IX, VWF and fibrinogen were higher in patients than in control women, in contrast to factor XI levels, which did not differ between cases and controls (Table 1). Factor VIII, factor IX, factor XI, VWF and fibrinogen levels increased with age. The mean age at blood sampling was $48 \mathrm{yr}$ (range 31-59) for patients and $44 \mathrm{yr}$ (range 22-59) for control women. The median time between the index date (date of MI in cases, or the matched date for controls) and blood draw was 5 yr (range 2-9). As expected, patients had a higher prevalence of classical risk factors at the index date than control women.

Table 2 shows that blood group non-O was found more frequently among patients than among control women $(47 \%$ vs. $33 \%)$, and women with

Table 1. Characteristics of the patients with myocardial infarction and control women, and mean levels of coagulation factors according to age categories

\begin{tabular}{|c|c|c|c|}
\hline & $\begin{array}{l}\text { Patients } \\
(n=200)\end{array}$ & $\begin{array}{l}\text { Control women } \\
\quad(n=626)\end{array}$ & $\begin{array}{c}\text { Mean } \\
\text { difference }(95 \% \text { Cl) }\end{array}$ \\
\hline Age, yr, mean (SD) & $48.7(6.1)$ & $44.8(8.4)$ & $3.9(2.4-4.9)$ \\
\hline Range & $31-59$ & $22-59$ & \\
\hline Factor VIII:C (IU/dL) & 133 & 111 & $22(15-29)$ \\
\hline $18-29$ yr & 139 & 103 & $36(5-66)$ \\
\hline $30-39$ yr & 123 & 107 & $16(11-30)$ \\
\hline $40-49$ yr & 136 & 117 & $19(10-28)$ \\
\hline $\begin{array}{l}\text { Von Willebrand } \\
\text { factor:ag (IU/dL) }\end{array}$ & 134 & 107 & $26(21-34)$ \\
\hline $18-29 \mathrm{yr}$ & 130 & 97 & $33(5-62)$ \\
\hline $30-39 \mathrm{yr}$ & 131 & 102 & $29(16-40)$ \\
\hline $40-49$ yr & 135 & 114 & $21(13-30)$ \\
\hline Factor IX:C (IU/dL) & 132 & 120 & $12(8-16)$ \\
\hline $18-29 \mathrm{yr}$ & 119 & 116 & $3(-15$ to 21$)$ \\
\hline $30-39 \mathrm{yr}$ & 124 & 117 & $7(-1$ to 14$)$ \\
\hline $40-49 \mathrm{yr}$ & 136 & 123 & 13 (7-19) \\
\hline Factor XI:C (IU/dL) & 114 & 113 & $1(-4$ to 6$)$ \\
\hline $18-29 \mathrm{yr}$ & 107 & 102 & $5(-11$ to 22$)$ \\
\hline $30-39$ yr & 105 & 103 & $2(-5$ to 9$)$ \\
\hline $40-49$ yr & 114 & 113 & $1(-4$ to 6$)$ \\
\hline Fibrinogen (g/L) & 3.53 & 3.20 & $0.33(0.23-0.45)$ \\
\hline $18-29 \mathrm{yr}$ & 3.18 & 3.09 & $0.09(-0.38$ to 0.58$)$ \\
\hline $30-39 \mathrm{yr}$ & 3.41 & 3.14 & $0.27(0.05-0.48)$ \\
\hline $40-49 \mathrm{yr}$ & 3.59 & 3.27 & $0.32(0.18-0.46)$ \\
\hline $\begin{array}{l}\text { C-reactive protein, } \\
\text { IQR (mg/L) }\end{array}$ & $\begin{array}{c}2.74 \\
(0.76 \text { to } \geq 10)\end{array}$ & $\begin{array}{c}1.34 \\
(0.50-4.97)\end{array}$ & $P<0.01^{1}$ \\
\hline Hypertension (\%) & $53(27)$ & $40(6)$ & $21(15-26)$ \\
\hline Diabetes (\%) & $10(5)$ & $10(2)$ & $3(1-6)$ \\
\hline Hypercholesterolaemia (\%) & $20(10)$ & $19(3)$ & $7(1-10)$ \\
\hline Obesity (\%) & $58(29)$ & $73(12)$ & $17(11-23)$ \\
\hline Smoking cigarettes (\%) & $164(82)$ & $267(43)$ & $39(32-47)$ \\
\hline
\end{tabular}

${ }^{1}$ Mann-Whitney U-test.

IQR, interquartile range.
Table 2. Odds ratios for myocardial infarction for blood group non-0 vs. 0 , for categories of factor VIII:C and VWF:ag

\begin{tabular}{|c|c|c|c|c|c|}
\hline & $\begin{array}{c}\text { Patients, } \\
n(\%)\end{array}$ & $\begin{array}{c}\text { Controls, } \\
n(\%)\end{array}$ & $\begin{array}{c}\text { Odds ratio }{ }^{1} \\
(95 \% \mathrm{Cl})\end{array}$ & $\begin{array}{l}\text { Odds ratio } \\
(95 \% \mathrm{Cl})\end{array}$ & $\begin{array}{l}\text { Odds ratio } \\
(95 \% \mathrm{Cl})\end{array}$ \\
\hline \multicolumn{6}{|l|}{ Blood group } \\
\hline 0 & 66 (33) & $293(47)$ & 1 & 1 & 1 \\
\hline Non-0 & $134(67)$ & & $6(1.1-$ & $1.3(0.9-1.9)^{2}$ & $1.2(0.9-1.8)^{4}$ \\
\hline \multicolumn{6}{|c|}{ Factor VIII:C (IU/dL) } \\
\hline$<100$ & $55(27)$ & 5 (47) & 1 & 1 & 1 \\
\hline $100-1$ & & 136 & 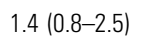 & $1.3(0.7-2.3)^{3}$ & $1.1(0.6-2.1)^{4}$ \\
\hline $125-150$ & $42(21)$ & 90 & $2.1(1.2-$ & $1.9(1.1-3.4)^{3}$ & $1.3(0.7-2.3)^{4}$ \\
\hline$\geq 150$ & $63(32)$ & $105(17)$ & $2.7(1.6-4.6)$ & $2.5(1.4-4.2)^{3}$ & $1.3(0.7-2.3)^{4}$ \\
\hline \multicolumn{6}{|c|}{ VWF:ag (IU/dL) } \\
\hline$<100$ & $50(25)$ & $10(50)$ & 1 & 1 & 1 \\
\hline $100-12$ & $50(25)$ & $141(22)$ & $2.4(1.2-4.7)$ & $2.4(1.2-4.7)^{3}$ & $2.3(1.2-4.6)^{2}$ \\
\hline $125-150$ & $32(1$ & 851 & $3.3(1.7-6.4)$ & $3.2(1.6-6.2)^{3}$ & $3.1(1.6-6.2)^{2}$ \\
\hline$\geq 150$ & $68(34)$ & $90(14)$ & $5.6(3.0-10.4)$ & $5.2(2.7-10)^{3}$ & $4.9(2.4-10)^{2}$ \\
\hline
\end{tabular}

$1=$ Reference category

Adjusted for stratification variables (age, index year and area of residence).

${ }^{2}$ Adjusted for stratification variables and factor VIII:C levels.

${ }^{3}$ Adjusted for stratification variables and blood group.

${ }^{4}$ Adjusted for stratification variables and VWF:Ag levels.

blood group non-O had a 1.6 fold $[95 \%$ confidence interval (CI) 1.1-2.3] increased risk of MI compared with those with blood group O. Adjusted for factor VIII levels, the OR for blood group non-O vs. O became $1.3(95 \%$ CI $0.9-1.9)$ and after adjustment for VWF levels 1.2 (95\% CI 0.9-1.8).

Mean factor VIII levels were lower in blood group O carriers (100 IU/dL, 95\% CI 96-104) compared with blood group non-O carriers (130 IU/dL, 95\% CI 125-134), with 95\% CI for mean difference 24-36 IU/dL. Mean VWF levels were lower in blood group $\mathrm{O}$ carriers $(97 \mathrm{IU} / \mathrm{dL}$, 95\% CI 93-100) compared with blood group nonO carriers (126 IU/dL, 95\% CI 122-130), 95\% CI for mean difference $24-35 \mathrm{IU} / \mathrm{dL}$. Factor VIII levels $>150 \mathrm{IU} / \mathrm{dL}$ were present in $32 \%$ of the patients and $17 \%$ of the control women, and increased the risk of MI more than twofold compared with factor VIII levels below $100 \mathrm{IU} /$ dL. The ORs remained virtually unaffected after adjustment for CRP, diabetes, hypertension, hypercholesterolaemia and obesity. However, after additional adjustment for VWF levels, the ORs for both categories of factor VIII levels $125-150 \mathrm{IU} / \mathrm{dL}$ and $\geq 150 \mathrm{IU} / \mathrm{dL}$ decreased to 1.3 (95\% CI $0.7-2.3)$.

Von Willebrand factor levels $>150 \mathrm{IU} / \mathrm{dL}$ were present in $34 \%$ of the patients and $14 \%$ of the control women, and increased the risk of MI 5.6fold $(95 \%$ CI 3.0-10.4) compared with factor VWF levels below $100 \mathrm{IU} / \mathrm{dL}$. The odds ratio remained high (OR 4.7; 95\% CI 2.3-9.7) after adjustment for the effect of blood group, while the dose-response relation persisted as well. Further adjustment for factor VIII, smoking, hypertension, hypercholesterolaemia, diabetes and obesity did not affect the ORs. 
Table 3. Risk effect of categorized fibrinogen and C-reactive protein levels in women with myocardial infarction and control women

\begin{tabular}{lrrrr}
\hline & $\begin{array}{c}\text { Patients, } \\
n(\%)\end{array}$ & $\begin{array}{c}\text { Controls, } \\
n(\%)\end{array}$ & $\begin{array}{c}\text { Odds ratio } \\
(95 \% \mathrm{Cl})\end{array}$ & $\begin{array}{c}\text { Odds ratio } \\
(95 \% \mathrm{Cl})\end{array}$ \\
\hline $\begin{array}{l}\text { Fibrinogen } \\
\quad\end{array}$ & & & & \\
$<2.5$ & $9(5)$ & $83(13)$ & 1 & 1 \\
$2.5-3.5$ & $97(49)$ & $361(58)$ & $1.8(1.2-2.7)^{1}$ & $1.6(1.0-2.4)^{2}$ \\
$3.5-4.5$ & $74(37)$ & $150(24)$ & $2.6(1.5-4.5)^{1}$ & $2.1(1.2-3.6)^{2}$ \\
$\geq 4.5$ & $19(10)$ & $27(4)$ & $2.3(0.8-6.6)^{1}$ & $1.5(0.5-4.5)^{2}$ \\
CRP (mg/L) & & & & 1 \\
$<0.50$ & $23(12)$ & $86(14)$ & 1 & \\
$0.50-1.34$ & $41(20)$ & $215(34)$ & $0.7(0.4-1.3)^{1}$ & $0.5(0.3-1.0)^{3}$ \\
$1.34-4.97$ & $79(39)$ & $211(34)$ & $1.4(0.8-2.4)^{1}$ & $0.8(0.5-1.5)^{3}$ \\
$\geq 4.97$ & $57(29)$ & $114(18)$ & $2.0(1.1-3.6)^{1}$ & $1.0(0.5-1.9)^{3}$ \\
\hline
\end{tabular}

$1=$ Reference category.

${ }^{1}$ Adjustment for stratification variables (age, index year and area of residence).

${ }^{2}$ Adjustment for stratification variables (age, index year and area of residence) and CRP.

${ }^{3}$ Adjustment for stratification variables (age, index year and area of residence), hypercholesterolaemia, diabetes and BMI.

${ }^{4}$ Fibrinogen was missing in 1 patient and 5 control women.

Table 3 shows the ORs for MI for different fibrinogen and CRP categories. The OR for MI in the highest quartile of CRP levels was $2.0(95 \% \mathrm{CI}$ 1.1-3.6) compared with those in the lowest quartile. After adjustment for hypercholesterolaemia, diabetes and BMI, the OR decreased to 1.0 (95\% CI 0.51.9).

Table 4 shows the risk of MI for various categories of factor IX levels. Adjustment for putative confounders attenuated the ORs for MI from 3.6 (95\% CI $1.8-6.7)$ to $2.6(95 \%$ CI $1.3-5.4)$ in the highest category with factor IX levels above $150 \mathrm{IU} / \mathrm{dL}$, compared with women who had factor IX levels below $100 \mathrm{IU} / \mathrm{dL}$. Mean factor IX levels were $134 \mathrm{IU} / \mathrm{dL}$ in oral contraceptive users compared with $115 \mathrm{IU} / \mathrm{dL}$ in non-users (mean difference $19 \mathrm{IU} / \mathrm{dL}, 95 \% \mathrm{CI} 15$ to 24 ). Adjustment for factor VIII levels did not change the ORs. ORs for categories with increasing factor XI levels were 1.1 (95\% CI $0.8-1.7), 1.0$ (95\% CI 0.6-1.7), and 1.6 (95\% CI 0.8-3.2) compared with the reference category.

Table 4. Odds ratios for myocardial infarction according to strata of factor IX:C levels (in $\mathrm{IU} / \mathrm{dL}$ )

\begin{tabular}{lcccc}
\hline & $\begin{array}{c}\text { Patients } \\
n(\%)\end{array}$ & $\begin{array}{c}\text { Control women, } \\
n(\%)\end{array}$ & $\begin{array}{c}\text { Odds ratio }^{2} \\
(95 \% \mathrm{Cl})\end{array}$ & $\begin{array}{c}\text { Odds ratio }^{3} \\
(95 \% \mathrm{Cl})\end{array}$ \\
\hline$<100$ & $18(10)$ & $133(21)$ & 1 & 1 \\
$100-125$ & $59(33)$ & $237(38)$ & $1.7(1.0-3.1)$ & $1.6(0.8-2.9)$ \\
$125-150$ & $61(34)$ & $187(30)$ & $2.2(1.2-4.0)$ & $1.3(0.6-2.4)$ \\
$\geq 150$ & $41(23)$ & $69(11)$ & $3.5(1.8-6.7)$ & $2.6(1.3-5.4)$ \\
\hline
\end{tabular}

$1=$ Reference category.

${ }^{1}$ Women on oral anticoagulation therapy were excluded from the analysis $(n=21)$. ${ }^{2}$ Adjusted for the stratification variables (age, index year and area of residence).

${ }^{3}$ Adjusted for stratification variables, hypertension, current smoking, obesity, family history of CVD and oral contraceptive use.

\section{Discussion}

In this study, we found that elevated levels of factor VIII, factor IX and VWF, defined as levels $>150 \mathrm{IU} / \mathrm{dL}$ compared with levels $<100 \mathrm{IU} / \mathrm{dL}$, were associated with an increased risk of MI in young women; the associations between these coagulation factor levels and MI were dosedependent. The most pronounced relationship was found between elevated VWF levels and MI with a fivefold increased risk. Blood group non-O was associated with an 1.6-fold increased risk of MI compared with blood group $\mathrm{O}$. This can be explained by the increased factor VIII and VWF levels, because the effect of blood group disappeared after adjustment for these factors. Although entirely explained by VWF and FVIII, blood group because of its high prevalence is an important genetic risk factor for $\mathrm{MI}$ in agreement with earlier results in women (32) and men (33). Conventional risk factors predominantly explain the association between elevated fibrinogen and CRP levels and MI in young women. Factor XI levels were not associated with MI.

\section{Von Willebrand factor}

High VWF levels were not only associated with arterial thrombosis $(13,34)$ but also with a history of diabetes and hypertension $(35,36)$. Von Willebrand factor is essential in primary haemostasis: it serves as the carrier protein of factor VIII and protects factor VIII against proteolysis, and plays a crucial role in platelet aggregation during thrombus formation under flow conditions. The large variation in plasma factor VIII levels is predominantly modulated by blood group (which explains about $30 \%$ of the genetically determined variation of VWF levels), and VWF [50\% of high factor VIII levels are associated with high VWF levels in venous thrombosis (37)], and to a lesser extent by other stimuli. Recently, linkage studies have shown a functional effect of ABO locus polymorphisms on VWF and factor VIII levels (38, 39). Generally, three mechanisms could explain the association of high levels of VWF and MI: first, its association with high levels of factor VIII at sites of vascular damage, promoting fibrin formation; secondly, by its primary action of promoting platelet aggregation at those sites; thirdly, while increased levels of VWF may be a marker for endothelial damage because of more extensive atherosclerosis in those with MI (14). In addition, early increase of VWF after unstable angina has been found to be a predictor of adverse outcome (40). In venous thrombosis, as we showed earlier, the first mechanism is predominant, because after mutual 


\section{Procoagulant factors and the risk of myocardial infarction}

adjustment of factor VIII and VWF levels, the effect of VWF levels disappeared while an effect of factor VIII levels remained (1). In this study of MI, we observed the opposite: after mutual adjustment, VWF levels remained associated with risk, while factor VIII levels did not.

Obviously, the association of non-O blood group with risk cannot be the result of endothelial damage, so we conclude that at least part of the association between high levels of VWF and MI is causal, and related to the effect on platelet aggregation. Apparently, secondary haemostasis plays a less prominent role in the coronary vascular bed, as opposed to the findings in venous thrombosis. The larger effect of antiplatelet agents in the prevention of arterial thrombotic events than in the prevention of venous thrombosis supports this view.

\section{Factor VIII, factor IX and factor XI}

High levels of factor VIII and IX were associated with a more than twofold increased risk of MI in contrast with high levels of factor XI. This suggests that there is a role for secondary haemostasis in the aetiology of coronary thrombosis, although less pronounced than for platelet aggregation. This is in line with the findings on the role of these procoagulant factors on the opposite side of the coagulation spectrum. Patients with haemophilia A and B have a strongly reduced risk of MI $(24,41)$ and carriers of haemophilia, with on average $50 \%$ of the normal level of factor VIII or factor IX, are moderately protected (42). Fully in line with our findings of no effect of elevated levels of factor XI, severe hereditary deficiency of factor XI did not protect against MI in a Jewish population (43).

\section{C-reactive protein and fibrinogen}

As factor VIII and fibrinogen are acute-phase proteins, that both rise in response to numerous stimuli, we have used CRP as a marker of acutephase reaction. The influence of an acute-phase response to the event itself on the coagulation factors was minimized because blood samples were drawn more than $2 \frac{1}{2} \mathrm{yr}$ after the event. However, ongoing inflammatory processes related to atherosclerosis could be expected to lead to elevated levels of factor VIII. Adjustment for CRP did not affect the risk estimates of high factor VIII levels. In our study, the association between MI in young women and CRP levels was completely explained by the presence of conventional risk factors. Earlier observations in women (44) men (27) and diabetics (45) showed reduction in risk estimates for CRP after adjustment for other cardiovascular risk factors.
Aspects of the study design

A strong aspect of our study is that we included women in a nation-wide study, including all university hospitals in the country and surrounding regional centres. This is the largest study among young women to date, and the inclusion of consecutively diagnosed cases renders selection bias unlikely. The blood samples were collected after the event and, therefore, for each of the analyses the possibility of post hoc changes on the coagulation parameters should be carefully considered. This is mainly so for factor VIII and VWF. However, the association with $\mathrm{ABO}$ blood group phenotypes can only be causal, and from this we have to built up the interpretation of the results.

We cannot exclude an effect of atherosclerotic disease on procoagulant factors in this casecontrol study, but did not find an association between the coagulation factors and the time that had elapsed since the MI, indicating the absence of acute effects of the event. It should be noted that this limitation would not even be solved by a prospective study design with blood samples taken prior to the MI, because patients with more extensive atherosclerosis are at higher risk of MI.

\section{Conclusions}

In the field of determinants of the risk of MI in young women, this study showed a confirmation of the role of elevated VWF, factor VIII and factor IX levels. Based on recent literature, VWF could be an important risk marker during multifactorial cardiovascular risk factor intervention in the near future $(35,36)$. These risk factors are dose-dependent and their variability in plasma has a measurable genetic component. Based on current data, we conclude that these procoagulant factors are related with both venous and arterial disorders. As these entities have traditionally been considered different diseases, this is an important point and supports the presence of common risk factors for venous and arterial thrombosis (46).

\section{Acknowledgements}

The RATIO-project was supported by a grant from the Netherlands Heart Foundation (grant 97-063). We gratefully acknowledge all women who participated in the RATIO-study.

\section{References}

1. Koster T, Blann AD, Briët E, Vandenbroucke JP, ROSENDAAL FR. Role of clotting factor VIII in effect of von Willebrand factor on occurrence of deep-vein thrombosis. Lancet 1995;345:152-155. 
2. Kamphuisen PW, Eikenboom JC, Vos HL, Pablo R, Sturk A, Bertina RM, RosendaAl FR. Increased levels of factor VIII and fibrinogen in patients with venous thrombosis are not caused by acute phase reactions. Thromb Haemost 1999;81:680-683.

3. Kraaijenhagen RA, in't Anker PS, Koopman MM, Reitsma PH, Prins MH, van den Ende A, Büller HR. High plasma concentration of factor VIIIc is a major risk factor for venous thromboembolism. Thromb Haemost 2000;83:5-9.

4. O'Donnell J, Laffan M. Elevated plasma factor VIII levels - a novel risk factor for venous thromboembolism. Clin Lab 2001;47:1-6.

5. Kamphuisen PW, Eikenboom JC, Bertina RM. Elevated factor VIII levels and the risk of thrombosis. Arterioscler Thromb Vasc Biol 2001;21:731-738.

6. Meijers JC, Tekelenburg WL, Bouma BN, Bertina RM, RosendaAl FR. High levels of coagulation factor XI as a risk factor for venous thrombosis. $\mathrm{N}$ Engl $\mathrm{J}$ Med 2000;342:696-701.

7. Van Hylckama Vlieg A, van der Linden I, Bertina RM, ROSENDAAL FR. High levels of factor IX increase the risk of venous thrombosis. Blood 2000;95:3678-3682.

8. Balleisen L, Bailey J, Epping PH, Schulte H, van de Loo J. Epidemiological study on factor VII, factor VIII and fibrinogen in an industrial population: I. Baseline data on the relation to age, gender, body-weight, smoking, alcohol, pillusing, and menopause. Thromb Haemost 1985;54:475-479.

9. Conlan MG, Folsom AR, Finch A, Davis CE, Sorlie P, Marcucci G, Wu KK. Associations of factor VIII and von Willebrand factor with age, race, sex, and risk factors for atherosclerosis. The Atherosclerosis Risk in Communities (ARIC) Study. Thromb Haemost 1993;70:380-385.

10. Tracy RP, Bovill EG, Yanez D, Psaty BM, Fried LP, Heiss G, Lee M, Polak JF, Savage PJ. Fibrinogen and factor VIII, but not factor VII, are associated with measures of subclinical cardiovascular disease in the elderly. Results from The Cardiovascular Health Study. Arterioscler Thromb Vasc Biol 1995;15:1269-1279.

11. Woodward M, Lowe GD, Rumley A, Tunstall-Pedoe H, Philippou H, Lane DA, Morrison CE. Epidemiology of coagulation factors, inhibitors and activation markers: The Third Glasgow MONICA Survey. II. Relationships to cardiovascular risk factors and prevalent cardiovascular disease. Br J Haematol 1997;97:785-797.

12. Medalie JH, Levene C, Papier C, Goldbourt U, Dreyfuss F, Oron D, Neufeld H, Riss E. Blood groups, myocardial infarction and angina pectoris among 10,000 adult males. N Engl J Med 1971;285:1348-1353.

13. Meade TW, Cooper JA, Stirling Y, Howarth DJ, RudDock V, Miller GJ. Factor VIII, ABO blood group and the incidence of ischaemic heart disease. Br J Haematol 1994;88:601-607.

14. Rumley A, Lowe GD, Sweetnam PM, Yarnell JW, FORD RP. Factor VIII, von Willebrand factor and the risk of major ischaemic heart disease in the Caerphilly Heart Study. Br J Haematol 1999;105:110-116.

15. Gill JC, Endres-Brooks J, Bauer PJ, Marks WJ Jr, Montgomery RR. The effect of ABO blood group on the diagnosis of von Willebrand disease. Blood 1987;69:16911695.

16. Caekebeke-Peerlinck KM, Koster T, Briët E. Bleeding time, blood groups and von Willebrand factor. Br J Haematol 1989;73:217-220.

17. Cucuianu MP, Cristea A, Roman S, Rus H, Missits I, PeChet L. Comparative behaviour of the components of the factor VIII complex in acute myocardial infarction. Thromb Res 1983;30:487-497.

18. Ross R. The pathogenesis of atherosclerosis - an update. N Engl J Med 1986;314:488-500.
19. Meade TW, Mellows S, Brozovic M, Miller GJ, Chakrabarti RR, North WR, Haines AP, Stirling Y, IMESON JD, THOMPSON SG. Haemostatic function and ischaemic heart disease: principal results of the Northwick Park Heart Study. Lancet 1986;2:533-537.

20. JANSSON JH, NiLSSON TK, Johnson O. Von Willebrand factor in plasma: a novel risk factor for recurrent myocardial infarction and death. Br Heart J 1991;66:351-355.

21. Thompson SG, Kienast J, Pyke SD, Haverkate F, van de Loo JC. Hemostatic factors and the risk of myocardial infarction or sudden death in patients with angina pectoris. European Concerted Action on Thrombosis and Disabilities Angina Pectoris Study Group. N Engl J Med 1995;332:635-641.

22. Folsom AR, Wu KK, Rosamond WD, Sharrett AR, Chambless LE. Prospective study of hemostatic factors and incidence of coronary heart disease: the Atherosclerosis Risk in Communities (ARIC) Study. Circulation 1997;96:1102-1108.

23. Rosendaal FR, Briët E, Stibbe J, van Herpen G, Leuven JA, Hofman A, Vandenbroucke JP. Haemophilia protects against ischaemic heart disease: a study of risk factors. Br J Haematol 1990;75:525-530.

24. Triemstra M, Rosendaal FR, Smit C, van der Ploeg HM, BRIËT E. Mortality in patients with hemophilia. Changes in a Dutch population from 1986 to 1992 and 1973 to 1986. Ann Intern Med 1995;123:823-827.

25. Ridker PM, Buring JE, Shih J, Matias M, Hennekens $\mathrm{CH}$. Prospective study of C-reactive protein and the risk of future cardiovascular events among apparently healthy women. Circulation 1998;98:731-733.

26. Ridker PM, Glynn RJ, Hennekens CH. C-reactive protein adds to the predictive value of total and HDL cholesterol in determining risk of first myocardial infarction. Circulation 1998;97:2007-2011.

27. Doggen CJ, Berckmans RJ, Sturk A, Manger Cats V, RosendAAL FR. C-reactive protein, cardiovascular risk factors and the association with myocardial infarction in men. J Intern Med 2000;248:406-414.

28. Davie EW, Fujikawa K, Kisiel W. The coagulation cascade: initiation, maintenance, and regulation. Biochemistry 1991;30:10363-10370.

29. Bouma BN, van den Borne PA, Meijers JC. Factor XI and protection of the fibrin clot against lysis - a role for the intrinsic pathway of coagulation in fibrinolysis. Thromb Haemost 1998;80:24-27.

30. Bouma BN, MeIJers JC. Role of blood coagulation factor XI in downregulation of fibrinolysis. Curr Opin Hematol 2000;7:266-272.

31. Tanis BC, van den Bosch MA, Kemmeren JM, Manger Cats V, Helmerhorst FM, Algra A, van der GraAf Y, ROSENDAAL FR. Oral contraceptives and the risk of myocardial infarction. N Engl J Med 2001;345:17871793.

32. Jick H, Dinan B, Herman R, Rothman KJ. Myocardial infarction and other vascular diseases in young women. Role of estrogens and other factors. JAMA 1978;240:25482552.

33. Whincup PH, Cook DG, Phillips AN, Shaper AG. ABO blood group and ischaemic heart disease in British men. BMJ 1990;300:1679-1682.

34. Sakai H, Goto S, Kim JY, Aoki N, Abe S, Ichikawa N, Yoshida M, Nagaoka Y, Handa S. Plasma concentration of von Willebrand factor in acute myocardial infarction. Thromb Haemost 2000;84:204-209.

35. Lim HS, Chong AY, Freestone B, Blann AD, Lip GY. The effect of multi-factorial intervention on plasma von Willebrand factor, soluble E-selectin and tissue factor in diabetes mellitus: implications for atherosclerotic vascular disease. Diab Med 2005;22:249-255. 


\section{Procoagulant factors and the risk of myocardial infarction}

36. Spencer CG, Gurney D, Blann AD, Beevers DG, Lip GY. ASCOT Steering Committee, Anglo Scandinavian Cardiac Outcome Trial. Hypertension 2002;40:61-66.

37. O’Donnell J, Mumford AD, Manning RA, LafFan M. Elevation of FVIII: $\mathrm{C}$ in venous thromboembolism is persistent and independent of the acute phase response. Thromb Haemost 2000;83:10-13.

38. Souto JC, Almasy L, Muniz-Diaz E et al. Functional effects of the ABO locus polymorphism on plasma levels of von Willebrand factor, factor VIII, and activated partial thromboplastin time. Arterioscler Thromb Vasc Biol 2000;20:2024-2028.

39. Rosendaal FR, Bovill EG. Heritability of clotting factors and the revival of the prothrombotic state. Lancet 2002;359:638-639.

40. Montalescot G, Philippe F, Ankri A et al. Early increase of von Willebrand factor predicts adverse outcome in unstable coronary artery disease: beneficial effects of enoxaparin. French Investigators of the ESSENCE Trial. Circulation 1998;98:294-299.

41. Rosendaal FR, Varekamp I, Smit C, Brocker-Vriends AH, van Dijck H, Vandenbroucke JP, Hermans J, SuurMEIJER TP, BRIËT E. Mortality and causes of death in Dutch haemophiliacs, 1973-86. Br J Haematol 1989;71:71-76.
42. ŠrámeK A, KrieK M, RosendaAl FR. Decreased mortality of ischaemic heart disease among carriers of haemophilia. Lancet 2003;362:351-354.

43. Salomon O, Steinberg DM, Dardik R, Rosenberg N, Zivelin A, Tamarin I, Ravid B, Berliner S, Seligsohn U. Inherited factor XI deficiency confers no protection against acute myocardial infarction. $\mathbf{J}$ Thromb Haemost 2003;1:658-661.

44. Ridker PM, Hennekens CH, Buring JE, Rifai N. $\mathrm{C}$-reactive protein and other markers of inflammation in the prediction of cardiovascular disease in women. $\mathrm{N}$ Engl $\mathbf{J}$ Med 2000;342:836-843.

45. Jager A, van Hinsbergh VW, Kostense PJ, Emeis JJ, Yudkin JS, Nijpels G, DekKer JM, Heine RJ, Bouter LM, Stehouwer CD. Von Willebrand factor, C-reactive protein, and 5-year mortality in diabetic and nondiabetic subjects: the Hoorn Study. Arterioscler Thromb Vasc Biol 1999; 19:3071-3078.

46. Prandoni P, Bilora F, Marchiori A, Bernardi E, Petrobelli F, Lensing AW, Prins MH, Girolami A. An association between atherosclerosis and venous thrombosis. N Engl J Med 2003;348:1435-1441. 